\title{
Working status and perception of adulthood: a comparison between Italian and Dutch emerging adults
}

\author{
Giovanni Piumatti ${ }^{1 *}$, Fabrizia Giannotta ${ }^{2}$, Antonella Roggero ${ }^{1}$ and Emanuela Rabaglietti ${ }^{1}$ \\ ${ }^{1}$ Department of Psychology, Laboratory of Developmental Psychology, University of Turin, Italy \\ ${ }^{2}$ Center for Developmental Research, School of Law, Psychology and Social Work, Örebro University, Sweden
}

\begin{abstract}
The purpose of this study was (a) to identify the criteria Italian and Dutch emerging adults consider important to achieve adulthood; (b) to compare Italian emerging adults' criteria with the criteria espoused by Dutch emerging adults; and (c) to examine how these criteria might differ on the basis of the working status (temporary job contract vs. permanent job contract) of the participants. Participants included 111 Italian $\left(M_{\text {age }}=25\right)$ and 151 Dutch $\left(M_{\text {age }}=22\right)$ university working students. Results revealed that (a) on average, Italian and Dutch emerging adults agreed upon the same order of importance for the criteria of adulthood presented to them; (b) Italian participants, more than Dutch participants, considered particularly important for defining the adult status the criteria related to family capacities; and (c) taking into account the working status of the participants, the answers differed only approaching significance. These findings have important implications for future research as they evidence that emerging adults experience their path to adulthood differently depending on their nationality. Specifically, the main contribution of this study is to have tested such hypotheses in a cross-national manner where contextual and individual differences are both taken into account.
\end{abstract}

Keywords: transition to adulthood, emerging adulthood, temporary job, Italy, Netherlands

\section{Zaposlitveni status in zaznavanje obdobja odraslosti: primerjava med italijanskimi in nizozemskimi mladimi odraslimi}

\author{
Giovanni Piumatti ${ }^{1}$, Fabrizia Giannotta ${ }^{2}$, Antonella Roggero ${ }^{1}$ in Emanuela Rabaglietti ${ }^{1}$ \\ ${ }^{1}$ Oddelek za psihologijo, Laboratorij za razvojno psihologijo, Univerza v Torinu, Italija \\ ${ }^{2}$ Center za razvojne raziskave, Šola za pravo, psihologijo in socialno delo, Univerza v Örebru, Švedska
}

\begin{abstract}
Povzetek: Namen pričujoče raziskave je bil (a) v identifikaciji kriterijev, ki jih italijanski in nizozemski mladi odrasli dojemajo kot pomembne za doseganje odraslosti; (b) v primerjavi italijanskih kriterijev mladih odraslih s tistimi od nizozemskih; (c) v proučevanju tega, kako so ti kriteriji povezani z zaposlitvenim statusom (začasno delovno razmerje proti stalnemu delovnemu razmerju). Udeleženci so bili italijanski $(M=25$ let) in nizozemski $(M=22$ let) študenti v delovnem razmerju. Rezultati so pokazali, da (a) se v povprečju italijanski in nizozemski mladi odrasli strinjajo o pomembnosti kriterijev za doseganje odraslosti; (b) so italijanski mladi odrasli, v primerjavi z nizozemskimi, večjo pomembnost pripisovali kriterijem, ki so povezani z zmožnostjo ustvarjanja družine; (c) da so razlike v povezavi z zaposlitvenim statusom bile zgolj na meji statistične pomembnosti. Dobljeni rezultati imajo pomembne implikacije za prihodnje študije, saj dokazujejo, da mladi odrasli različno dojemajo kriterije za doseganje odraslosti v odvisnosti od narodnosti. Natančneje je glavni doprinos raziskave v preverjanju naših domnev v dveh državah, kjer smo hkrati upoštevali tako kontekstualne kot individualne razlike.
\end{abstract}

Ključne besede: prehod v odraslost, merila odraslosti, zaposlitveni status, Italija, Nizozemska

\footnotetext{
"Naslov/Address: Giovanni Piumatti, Laboratory of Developmental Psychology, Department of Psychology, University of Turin, Via Verdi 10, 10124 Torino (Italy), Office: +39 0116702788, Mobile: +39 3335251387, e-mail: giovanni.piumatti@gmail.com

Članek je licenciran pod pogoji Creative Commons Attribution 4.0 International licence. (CC-BY licenca).

The article is licensed under a Creative Commons Attribution 4.0 International License (CC-BY license).
} 
The term emerging adulthood was proposed by Arnett (2000) to define a developmental period distinct from both adolescence and adulthood and pertaining to individuals in modern Western industrialized cultures. This period's main features are identity exploration processes in the areas of love, work and worldviews, instability, being self-focused, feeling somewhere in between, and looking forward to and experiencing various future possibilities in life (Arnett, 2001).

The construct of emerging adulthood is also embedded in socio-cultural contexts (Arnett \& Galambos, 2003). Researches in Finland and Poland (Trempala \& Malmberg, 1998), North America (Arnett, 2003), Israel (Mayseless \& Scharf, 2003), Argentina (Facio, Resett, Micocci, \& Mistrorigo, 2007), Austria (Sirsch, Dreher, Mayr \& Willinger, 2009) and Greece (Petrogiannis, 2011) showed that culture and nationality have a distinct effect on emerging adults' view on adulthood. Other researches have also highlighted how the perception one has of him/ herself as still a youth and/or already an adult is related to age, gender, marital status and the level of education received (Buhl, 2007; Fadjukoff, Kokko \& Pulkinnen, 2007; Fierro \& Hernández, 2007; Lanz \& Tagliabue, 2007; Macek, Bejcek \& Vanýckova, 2007). Anyhow, the transition to adulthood remains a conventional construct and one of the key issues is whether and which conditions or events signify the adult status.

Research has particularly looked at those demographic shifts where transitions take place in modern societies (e.g., education-to-work transitions, leaving parental home, getting married) and where most changes have occurred in the last decades (Hoyer \& Rybash, 1994; Modell, Furstenberg, and Hershberg, 1976; Newton, 1994). Nowadays, it is crucial to constantly update findings with regard to the changes occurring in the society and the extents to which these can affect individuals' transitions. However, country-based studies lack of insight into specific differences between individuals across countries. Contrariwise, cross-national studies can improve our knowledge on how individual differences might be moderated by contexts' variables. In the current study we compared the criteria emerging adults in Italy and in the Netherlands consider important to achieve adulthood. Specifically, we examined how these criteria might differ on the basis of emerging adults' working status (temporarily employed vs. permanently employed) in the two national contexts.

\section{Working status and transition to adulthood}

In modern labour markets the impact of the increasing adaptation to flexibility is highly debated. As a result of the deregulation of labour markets, atypical employment conditions, such as temporary jobs, are expanding among workers (Voss, 2013). Temporary work or temporary employment refers to a situation where the employee is expected to terminate the job contract within a certain period of time (OECD, 2002). Temporary jobs are usually paid less, they offer less training, and are less satisfying than regular jobs (Booth, Francesconi \& Frank 2002; Kahn, 2007). Temporary workers may work full-time or part-time, depending on the individual case. In some instances, they receive benefits (such as health insurance), but usually benefits are only given to permanent employees (Kahn, 2009). Here, we will refer to temporary and precarious working status in an exchangeable way to characterize individuals who do not have a permanent employment.

Young people in the European Union are four times as likely as adults to be temporary employees, while 41 per cent of the youth working as temporary employees in 2010 were students (International Labor Organization, 2012). Some of them engage in these non-standard arrangements out of choice, but many others do so often out of necessity, not preference, since these jobs are not expected to last (Barker \& Christensen, 1998; Cohany, Hipple, Nardone, Polivka, \& Stewart, 1998; Polivka, 1996). Moreover, atypical jobs create insecure work positions (Dolado, García-Serrano \& Jimeno, 2002; Schömann, Rogowski \& Kruppe, 1998). In fact, from the point of view of the workers, engaging in these kinds of precarious work positions often means facing an employment status which is uncertain, unpredictable and risky and results in variety forms of distress (Kalleberg, 2009). Research has found that a precarious job condition may affect the psychological adjustment of people similarly to that of unemployment (De Witte, 2005; Sverke \& Hellgren, 2002) and that the impact of job uncertainty and insecurity has been observed on an individual's health, stress and on one's identity corrosions and anomie's promotions (De Witte, 1999; Sennet, 1998; Sutin \& Costa, 2010; Uchitelle, 2006). Besides, job insecurity may have adverse psychological effects in terms of psychosomatic symptoms and anxiety, high rates of depression, and low levels of life satisfaction and self-esteem (e.g., Ciairano, Rabaglietti, Roggero, \& Callari, 2010; McKee-Ryan, Song, Wanberg, \& Kinicki, 2005; Paul \& Moser, 2009). Thus, focusing on young adults' first entry into the labour market when studying the transition to adulthood is crucial if we consider this transition as a step-by-step process in which individuals take on responsibilities in various life domains and increasingly participate in "adult activities" (Corijn \& Klijzing, 2001; Hogan \& Astone, 1986). Overall, the actual sociological challenges lead to insecurity of educationto-work transitions and early labour market careers, diversification of living arrangements and prolongation of family formation processes (Baizán, 2001; Golsch, 2003; Simó Noguera, Castro Martín \& Soro Bonmatí, 2001). However, the relationship between the new trends of job precariousness, and in particular short-term work contracts, and developmental role status of youths has not been fully investigated. For these reasons, how young adults are coping with the developmental tasks of the transition to adulthood might depend also on how they are dealing with their first job experiences. 
According to the conservation of resources theory (Hobfoll, 1989), a perceived lost of resources in one domain (e.g., a secure job) would lead to higher importance of resources in other individual personal domains (e.g., family, friends). When it comes to emerging adulthood, young adults with a stable employment are pushed towards the realization of specific identity-related goals (e.g., being independent from their parents) (Staff, Sabates, Harris, \& Briddell, 2011) that otherwise would be impossible to reach on their own. In particular, for emerging adults it is still common to experience ambivalences in life-directions and repeatedly turn to different sources of support (Arnett, 1998). The types and the fonts of support they are able to get from the environment can change their view of adulthood (Briulotta, 2009; De Lillo, 2007). Numerous studies (e.g., Arnett, 1998; Facio \& Micocci, 2003; Nelson $\&$ Barry, 2005) have documented that across cultures the criteria contemporary emerging adults use to distinguish adulthood center around (a) being independent and selfreliant, (b) being able to form mature relationships, (c) being able to comply with social norms, (d) being able to provide and care for a family. By failing in gaining confidence from their jobs for the independence they seek as pertaining to the areas described above, emerging adults might turn to a different conception of adulthood related to others areas of their lives. It seems therefore reasonable to hypothesize that different working status conditions but also different contexts might affect an individual's subjective developmental status and perception of those criteria, attitudes and behaviors that emerging adults consider markers of an adult life.

Contextual conditions, such as sectoral decline or growing shares of nonpermanent employment may also moderate the perception of job insecurity and precarious employment (Ferrie, Westerlund, Virtanen, Vahtera, \& Kivimki, 2008; Vives, et al., 2013). Especially among young workers, the subjective appraisal of such condition may be closer to individual internalizing and externalizing behaviors than to the actual conditions and social relations of employment (Amable, Benach, \& González, 2001; Aronsson, Gustafsson, \& Dallner, 2002). That is to say that how individuals cope with these forms of employment conditions might reasonably differ from country to country depending on how the negative aspects of social uncertainty and specific flexible policies for the job market are contained and established at the national level.

\section{Temporary employment and transition to adulthood in Italy and the Netherlands}

Italy and the Netherlands are an interesting case for cross-nationally testing the hypothesis described above, as they differ with respect to labour policies (Hesselink \& van Vuuren, 1999) and unemployment rate among youths (Statistics Netherlands, 2011; ISTAT, 2012). The
Dutch labor market is characterized by a relatively high degree of part-time work in newly created jobs, and a "flexicurity" approach which optimizes flexibility as well as work security (Wilthagen, 1998). On the other hand, the peculiarities of the Italian context seem to lead to a general delay syndrome, which is related to different aspects of individual adjustment as identity development (Crocetti, Rabaglietti, \& Sica, 2012) and the construction of a new family (Roggero, Vacirca, Mauri, \& Ciairano, 2012). While in Italy the role of the family is central to the societal organization (Naldini, 2003), in the Netherlands youths usually leave the parental house well before marriage. Thanks to economical government supports per capita, Dutch adolescents can reach partial independence at the age of 18 when they start to attend university. Furthermore, Dutch parenting seems mainly based on endorsement of autonomy (Meeus, 2006). On the other side, the age at which Italian young adults live the parental home is delayed with respect to others European countries due to the delayed age of marriage, low-rates of pre-marital cohabitation and high unemployment (Cook \& Furstenberg, 2002). As a result, the procrastination of leaving home has made familial relationships more tied than in the past, favoring economical and psychological independence among family's members (Buzzi, Cavalli \& De Lillo, 2002; Scabini, Lanz \& Marta, 2006). Summarizing, Dutch young adults develop values that promote independence more easily and especially sooner than their Italian peers. On the contrary, Italians seems to be oriented to foster emotional bonding with families even in a developmental moment when these bonds are supposed to decrease. These existing differences make these countries ideal settings to investigate the topic of the transition to adulthood in relation also to emerging adults' working status.

\section{Research aims and hypotheses}

The purpose of this study is twofold. First, we aimed at identifying and comparing the criteria emerging adults in Italy and in the Netherlands consider important in order to achieve adulthood. Secondly, we intended to examine how these criteria might differ on the basis of emerging adults' working status (temporarily employed vs. permanently employed) in the two national contexts. We hypothesized that Italian emerging adults would be less likely than Dutch ones to highlight individualistic criteria as important to define adulthood and more likely to focus on collectivistic and relational ones. Specifically, it was hypothesized that emerging adults in Italy would be more likely than their peers in the Netherlands to adopt family values to define adulthood. Finally, we also hypothesized that young people in temporary employment, with respect to their peers who are characterized by a stable working condition could attribute less importance to some events traditionally considered as "markers" of adulthood (e.g., reaching economic independence, leaving the house of the parents, having children of their own). In conditions of a 
temporary job, other aspects that are considered "markers" of adulthood can have a stronger importance among the young people experiencing this type of working status, such as those connected to a dimension of self-realization in a personal domain (e.g., the acquisition of a stable job, the maintenance of good relations with parents, friends or partners). However, we expect that the relationships between job condition and youths' adulthood perception would be moderated by nationality.

\section{Method}

\section{Participants}

The participants were students of the University of Turin's (Italy) and of the University of Amsterdam (The Netherlands). Questionnaires were submitted in an informed anonymous form during lessons' hours in presence of the researchers and previous professors' consensus and in others university's settings such as libraries, canteens, cafeterias and public leisure spaces. The criterion to include participants in this research was age, in a range of 18 to 30 years old, and the condition of "working student" at the time of data collection. The total number of participants included 111 Italian unmarried university students $\left(M_{\text {age }}=25.59 ; S D=2.81\right.$; Range $=20$ $30)$ and a 151 Dutch unmarried university students $\left(M_{\text {age }}\right.$ $=22.47 ; S D=2.73 ;$ Range $=18-30)$. The Italian group was composed by 52 males $46.8 \%$ ) and 59 females (53.2\%) with 37 people having a stable working contract (33.3\%) and 74 a temporary working contract $(66.7 \%)$. In the Dutch group there were 67 males (44.4\%) and 84 females (55.6\%) with 79 people having a stable working contract (52.3\%) and 72 a temporary working contract (47.7\%). Among Italian participants $92(82.9 \%)$ declared to be single and $19(17.1 \%)$ declared to be in a relationship. For the Dutch group these proportions equaled respectively $122(80.8 \%)$ and $29(19.2 \%)$.

\section{Measures}

The instrument of data collection included the scale of criteria for the transition to adulthood by Nelson et al. (2007). The questionnaire also included sociodemographic and occupational variables (e.g., age, gender, relationship status, type of working contract). Two versions of the questionnaire (one in Italian and one in Dutch), were created by translating and back translating them by native speakers.

Criteria for adulthood. As an assessment of criteria for adulthood, the participants were presented with a list of possible criteria for adulthood (e.g., "Finishing education", "Avoid drunk driving", "Purchasing a house") (Arnett, 2003). In particular, participants were asked to "give your opinion on the importance of each one of the following in determining whether or not a person has reached adulthood". They could rate each item from 1 (not at all) to 4 (very important). These measures have been commonly used in other adolescent and young adult populations (e.g., Barry \& Nelson, 2005; Cheah \& Nelson, 2004). The way in which the criteria were grouped into categories in the current study is based upon such previous research (Badger, Nelson \& Barry, 2006). The general scale was grouped into five categories, each one representing certain aspects related to a specific dimension commonly addressable to adulthood: Biological and Age Transitions, Norm Compliance, Relational Maturity, Role Transitions and Family Capacities. The organization of the subscales was obtained through a theory based approach rather than by a quantitative statistical approach such as factor analysis (Arnett, 2001). Specifically, the items of the Family Capacities subscale were all drawn from the anthropological literature, which has identified gender-specific criteria used in many traditional cultures as criteria for the transition to adulthood (Gilmore, 1990). Similarly, the items on the Role Transitions subscale were drawn from the sociological literature, which has long used a series of specific role transitions as the defining criteria for the transition to adulthood (Goldscheider \& Goldscheider, 1999; Hogan \& Astone, 1986). The analysis of internal consistency pointed out that alpha levels of these subscales were considerably better in our sample than in previous studies, where internal consistency has always been moderate or low (e.g., Arnett, 2003; Nelson \& Barry, 2005; Sirsch et al., 2009): Biological and Age Transitions' Cronbach's $\alpha=.88$ and .87 , for the Italian and the Dutch groups respectively; Norm Compliance .82 and .81; Relational Maturity .73 and .67; Role Transitions .77 and .81; Family Capacities .83 and .87. Indeed, such previous studies failed to fully replicate these factors (Badger et al., 2006; Mayseless \& Scharf, 2003). Therefore, Arnett's conceptual model shows high face validity, whereas statistical evidence for this model might lack (e.g., Barker \& Galambos, 2005). However, since to our knowledge only one study has tested this kind of measure with a cross-national design between a sample of North American and Chinese young adults (Badger, Nelson \& Barry, 2006), we conducted a confirmatory factor analysis to investigate whether the items were interpretable along these five dimensions in our European sample. The model yielded an acceptable fit $\left(\chi^{2}=241.09, d f=71, \mathrm{p}<.001, \mathrm{CFI}\right.$ $=.94, \mathrm{TLI}=.91 ; \mathrm{RMSEA}=.06)$, suggesting that the items load well on the five factors.

\section{Analysis}

Before proceeding to analyze the data, all the scores of the items for each sub-scale were examined for the accuracy of data entry, detecting and replacing missing values, identifying univariate and multivariate outliers. We also examined the data for detecting multicollinearity and nonnormal distribution among dependent variables. Given the sample size, Italian and Dutch were not analyzed separately. If a model cannot be fitted to the combined sample, national differences might be the reason for that. If however it is observed, on the other hand, that a single 
model can describe the data well, we can assume that the data do not contain relevant national differences.

To check the means and frequencies of the variables representing background characteristics, a series of ttests for independent samples and Chi squares tests were performed. In addition, t-tests for independent samples (i.e., Italian and Dutch groups) were also performed on the answers to all sub-scales' items as well as for subscales' scores. In a further step, multivariate analysis of variance (MANOVA) was conducted for testing main and interaction effects of the variables nationality, working status and relationship status on importance's scores for adulthood criteria while controlling for participants' age and gender. Lastly, univariate analyses of variance (ANOVA) were carried out as follow-up to the results of MANOVA. In the MANOVA all main effects of the backgrounds characteristics were included. In this way, we could better test our hypothesis about differences due to the working status and its interaction with nationality.

\section{Results}

\section{Preliminary analysis}

No transformation of the distributions was found that can accommodate the model well. Based on previous studies (Barbaranelli \& D’Olimpio, 2007; Harlow, 1985; Muthén \& Kaplan, 1985) we considered acceptable values of skewness and curtosis between -1 and 1. According to these rules of thumbs, the assumption of the normality of the distribution for the variables of our study was met, with values of skewness and curtosis ranging respectively from -.820 to .263 and from -.921 to .697. Given the significant low rates of missing values on each item of the scales, we performed total mean substitution for each missing value. This decision was also made since no systematic correlation between these missing values and the scores of other variables among these subjects was detected ( $r$ $<|.20|$ ) (see Raaijmakers, 1999). Therefore, no case was excluded from further analysis.

To examine the extent to which each category/ criterion of adulthood reflects separate aspects, bivariate correlations using Pearson $r$ coefficient were run. Correlations among the subscales were small to moderate in magnitude (ranging from $r=.11$ to $r=.55$ ) confirming that these domains in which adult status is expected to be demonstrated reflect different facets or markers of adulthood. Similar results were obtained in previous studies (e.g., Petrogiannis, 2011) and should not present problems in terms of dependent variables' multicollinearity (Field, 2009).

\section{Descriptive statistics}

The average age was significantly higher in the Italian group $(M=25.59, S D=2.81)$ than in the Dutch one $(M=22.47, S D=2.72), t(262)=8.91, p<.001$. Also, the relationship between individuals' nationality and working status was significant, $X^{2}(1,262)=9.345, p<$ .01 , evidencing a higher incidence of stable working contracts in the Dutch group than in the Italian group. These differences between the groups are due to the characteristics of the normal populations. In fact, the youngest age at which at least $50 \%$ of young people are already in the labour market is 23 in Italy and 16 in the Netherlands (Eurostat, 2009).

Table 1 reports descriptive statistics for all the items as well as for every sub-scale according to participants' nationality. Reading from the results of the t-tests, Italians scored significantly higher than Dutch regarding the degrees of importance attributed to the adulthood criteria for Family Capacities, $t(262)=-5.22, p<.001$, Norm Compliance, $t(262)=-3.80, p<.001$, and Role Transitions, $t(262)=-5.83, p<.001$.

\section{Results of MANOVA and ANOVAs}

A MANOVA examined the association between the five categories of criteria of adulthood as dependent variables (DVs), and age, gender, nationality, relationship status and working status as independent variables (IVs). The multivariate result was significant for gender, Pillai's Trace $=.07, F=3.57, d f=(5,262), p<.01$, nationality, Pillai's Trace $=.09, F=4.96, d f=(5,262), p<.001$, and relationship status, Pillai's Trace $=.06, F=3.01, d f=(5$, $262), p<.05$. Among interaction effects, nationality with working status was approaching significance, Pillai's Trace $=.04, F=2.17, d f=(5,262), p=.058$, while all others interaction terms were nonsignificant (see Table 2).

Given the significance of the overall test, the univariate main effects were examined (see Table 3). These results indicate that on each of these criteria females scored significantly higher than males, Italian scored significantly higher than Dutch and those participants in a relationship scored significantly higher than those who declared to be single.

\section{Discussion}

The purpose of this study was (a) to identify the criteria Italian and Dutch emerging adults consider to be important to achieve adulthood; (b) to compare Italian emerging adults' criteria with the criteria espoused by Dutch emerging adults; and (c) to examine how these criteria might differ on the basis of the working status (temporary job contract vs. permanent job contract) of the participants. Results revealed that (a) on average, Italian and Dutch emerging adults agreed upon the same order of importance for the criteria of adulthood presented to them; (b) Italian participants, more than Dutch participants, considered particularly important the criteria related to family capacities for defining the adult status; and (c) taking into account the working status of the participants, 
Table 1. Descriptive statistics for items and sub-scales by nationality

\begin{tabular}{|c|c|c|c|c|c|c|}
\hline & \multicolumn{2}{|c|}{$\begin{array}{l}\text { Italian } \\
(N=111)\end{array}$} & \multicolumn{2}{|c|}{$\begin{array}{l}\text { Dutch } \\
(N=151)\end{array}$} & \multirow{2}{*}{$\begin{array}{c}t \\
(d f=260)\end{array}$} & \multirow[b]{2}{*}{$p$} \\
\hline & $M$ & $S D$ & $M$ & $S D$ & & \\
\hline Family Capacities & 3.56 & .59 & 3.08 & .84 & -5.22 & .000 \\
\hline 1. Be able to financially support a family & 3.55 & .68 & 2.87 & 1.03 & -6.01 & .000 \\
\hline 2. Be able to take care of the children & 3.49 & .72 & 3.19 & .93 & -2.83 & .005 \\
\hline 3. Be able to ensure safety to the family & 3.65 & .64 & 3.17 & .86 & -4.95 & .000 \\
\hline Relational Maturity & 3.28 & .53 & 3.18 & .51 & -1.68 & .094 \\
\hline $\begin{array}{l}\text { 4. Accept the responsibility of the consequences of your own } \\
\text { actions }\end{array}$ & 3.83 & .40 & 3.68 & .52 & -2.47 & .014 \\
\hline 5. Establish an equal relationship with your parents & 3.29 & .78 & 2.91 & .85 & -3.72 & .000 \\
\hline 6. Learn to have always a good control of your own emotions & 3.06 & .79 & 2.96 & .80 & -1.03 & .302 \\
\hline 7. Become less self-oriented & 2.95 & .79 & 3.15 & .65 & 2.21 & .028 \\
\hline Norm Compliance & 3.18 & .55 & 2.90 & .60 & -3.80 & .000 \\
\hline 8. Avoid to get drunk & 2.61 & 1.03 & 1.95 & .93 & -5.47 & .000 \\
\hline 9. Avoid to drive being drunk & 3.60 & .74 & 3.56 & .70 & -.53 & .598 \\
\hline 10. Avoid to use illegal substances & 3.25 & .93 & 2.50 & 1.13 & -5.78 & .000 \\
\hline 11.Have no more than one sexual partner & 2.77 & 1.02 & 2.24 & 1.06 & -4.11 & .000 \\
\hline 12. Avoid to commit little crimes, as vandalism and shoplifting & 3.67 & .68 & 3.40 & .75 & -2.97 & .003 \\
\hline 13. Drive in security without go over the limits & 3.06 & .80 & 3.43 & .81 & 3.71 & .000 \\
\hline 14. Avoid to use vulgar and profane language & 2.55 & .88 & 2.55 & .91 & .00 & .999 \\
\hline 15. Use contraceptive methods to not get an unwanted pregnancy & 3.34 & .88 & 3.19 & .92 & -1.29 & .197 \\
\hline 16. Have safe sex to avoid sexually transmitted diseases & 3.73 & .59 & 3.31 & .86 & -4.40 & .000 \\
\hline Role Transitions & 2.93 & .61 & 2.47 & .64 & -5.83 & .000 \\
\hline 17. Be economically independent from the parents & 3.59 & .64 & 3.09 & .86 & -5.10 & .000 \\
\hline 18 Live no more in the house of the parents & 3.09 & .87 & 3.37 & .91 & 2.51 & .013 \\
\hline 19. Have completed Your studies & 3.18 & 1.00 & 3.11 & .94 & -.56 & .577 \\
\hline 20. Be married & 2.14 & 1.08 & 1.56 & .87 & -4.82 & .000 \\
\hline 21. Have at least one child & 2.32 & 1.14 & 1.83 & 1.07 & -3.55 & .000 \\
\hline 22. Have a job with a long time contract & 3.20 & .85 & 2.34 & .94 & -7.57 & .000 \\
\hline 23. Buy an house & 2.98 & .92 & 1.97 & .95 & -8.58 & .000 \\
\hline Biological and Age Transitions & 2.18 & .77 & 2.03 & .73 & -1.61 & .109 \\
\hline 24. Become 18 years old & 2.38 & 1.06 & 2.36 & .94 & -.10 & .924 \\
\hline 25. Become 21 years old & 2.33 & 1.02 & 2.44 & .96 & .91 & .364 \\
\hline 26. Grow up till the final height & 1.88 & .95 & 1.86 & .90 & -.19 & .849 \\
\hline 27. Be biologically able to conceive children & 2.58 & 1.20 & 2.01 & 1.10 & -3.95 & .000 \\
\hline 28. Have achieved the driving license & 2.65 & 1.17 & 1.98 & 1.02 & -4.93 & .000 \\
\hline 29. Have had sex & 2.33 & 1.08 & 2.06 & 1.16 & -1.95 & .053 \\
\hline 30. Be allowed to drink alcohol & 1.72 & .87 & 1.95 & 1.05 & 1.92 & .057 \\
\hline 31. Be allowed to smoke cigarettes & 1.59 & .85 & 1.58 & .92 & -.07 & .942 \\
\hline
\end{tabular}

the answers differed only approaching significance. In sum, it has been evidenced that the main source of differentiation between Italian and Dutch emerging adults in terms of what it is important for being an adult is related to the nationality, the gender and the relationship status of the participants.

Like emerging adults in the United States, Argentina or Austria (Facio, Resett, Micocci, \& Mistrorigo, 2007; Nelson \& Barry, 2005; Sirsch et al., 2009), Italian and Dutch emerging adults showed high levels of consent regarding the five defining features for adulthood. These results evidence once again that different cultures share a common view regarding the markers of adulthood. In fact, Italian and Dutch young adults appear to embrace the individualism of the western, North-European and American culture. On one hand, they mainly endorse criteria for adulthood related to dimensions such as accept responsibility for your actions and decide on personal beliefs and values. However, at the same time, they are likely to deem as important those criteria related to Family Capacities and Norm Compliance. These values represent the more traditional cultural values of family obligations and consideration for others. In addition, both national groups reject biologically and legally attributed features such as turning a certain age or getting married and becoming a parent or being allowed for certain actions.

By looking at the answers on these criteria it is possible to formulate further hypotheses on the differences between 
Table 2. Multivariate main and interaction effects for age, gender, nationality, working status, and relationship status

\begin{tabular}{lcccc}
\hline Source & Pillai's Trace & $F$ & $d f$ & Error $d f$ \\
\hline Age & .01 & 0.46 & 60 & 1100 \\
Gender & .07 & $3.57^{* *}$ & 5 & 248 \\
Nationality & .09 & $4.96^{* * *}$ & 5 & 248 \\
Working status & .03 & 1.50 & 5 & 248 \\
Relationship status & .06 & $3.01^{*}$ & 5 & 248 \\
Age * Nationality & .24 & 1.24 & 45 & 1100 \\
Age * Working status & .01 & 0.51 & 60 & 1100 \\
Gender * Relationship status & .02 & 0.90 & 5 & 216 \\
Gender * Working status & .04 & 1.69 & 5 & 216 \\
Nationality * Working status & .01 & 0.40 & 5 & 216 \\
Nationality * Relationship status & .02 & 0.99 & 5 & 216 \\
\hline
\end{tabular}

${ }^{*} p<.05,{ }^{* *} p<.01,{ }^{* * *} p<.001$.

Table 3. Statistically significant $(p<.05)$ univariate effects for gender, nationality and relationship status

\begin{tabular}{|c|c|c|c|c|c|}
\hline Dependent variables & Independent variables & $M(S D)$ & $F^{\mathrm{a}}$ & $M S E$ & $\eta^{2}$ \\
\hline \multirow[t]{6}{*}{ Norm Compliance } & Males & $2.87(.62)$ & 14.48 & 4.80 & .05 \\
\hline & Females & $3.14(.53)$ & & & \\
\hline & Dutch & $2.90(.60)$ & 14.42 & 4.78 & .05 \\
\hline & Italian & $3.18(.55)$ & & & \\
\hline & Single & $2.96(.60)$ & 11.06 & 3.71 & .04 \\
\hline & In a relationship & $3.27(.49)$ & & & \\
\hline \multirow[t]{4}{*}{ Family Capacities } & Dutch & $3.08(.84)$ & 27.19 & 15.08 & .10 \\
\hline & Italian & $3.56(.59)$ & & & \\
\hline & Single & $3.23(.81)$ & 6.59 & 3.93 & .03 \\
\hline & In a relationship & $3.54(.58)$ & & & \\
\hline \multirow[t]{4}{*}{ Role Transitions } & Dutch & $2.47(.64)$ & 33.96 & 13.44 & .12 \\
\hline & Italian & $2.93(.61)$ & & & \\
\hline & Single & $2.61(.65)$ & 8.28 & 3.59 & .03 \\
\hline & In a relationship & $2.91(.71)$ & & & \\
\hline
\end{tabular}

${ }^{\text {a }}$ The degrees of freedom for all $F$ ratios were 1 (effect) and 260 (error).

national groups. For Dutch young adults, capacities related to the sphere of family abilities such as sustaining a family, and those regarding relational maturity such as maintaining good relationships with friends and relatives are on the same level. Instead, Italian young adults keep these two areas on different levels considering as the most important criterion for becoming an adult what a person is able to do for having and maintaining a family. This attitude could be the consequence of the actual amount of engagement and commitment Italian emerging adults feel towards their family of origin. In this sense, results from the groups of individuals from Italy reflect how much the goal of forming a family in the future is crucial for their adult lives. Different cultural perceptions of what are the important criteria for reaching adulthood have been previously explained by individualistic vs. collectivistic societies' values (e.g., Badger, Nelson, \& Barry, 2006; Piumatti, Pipitone, Di Vita, Latina, \& Rabaglietti, 2013). Although the shared markers emphasize individualism, at the same time, they include collectivistic views. In fact, Family Capacities together with Relational Maturity and Norm Compliance are all ranked here as important for adult status. These clusters of items involve not only individualistic qualities but also responsibility to and consideration for others and may be considered as counterbalancing individualism by attributing importance to social and communal concerns (Arnett, 1998; Petrogiannis, 2011). Previous research has shown how Italian emerging adults stay with their families of origin to reinforce their position in the job market and prefer to abandon the family nest only after achieving economic independence (Briulotta, 2009). Only after the consolidation of their economic independence they can confidently move on and thinking about getting married or having a child. Therefore, we can read their intention of focusing more on family and affections in order to achieve their goals of personal fulfillment in these same areas in the future. Indeed, it is important to point out that the received support from the family of origin is itself a significant aspect of the Italian context. In a study conducted by Paleari, Rosnati and Lanz (2002), which involved entire family nuclei from Italy, that is, immediate 
and extended family members, they noted that the support received from one's own family has an essential role in the psychological well-being of the young adult. On the other hand, Dutch emerging adults are already preparing for the impending transition to adulthood and therefore are freer in engaging in identity work (Crocetti, Schwartz, Fermani, Klimstra, \& Meeus, 2012). Since they have already achieved more than their Italian peers in terms of autonomy along the path to adulthood, they are more inclined to develop values that promote independence. Over the years, these conditions promote a perception of adulthood primarily in terms of individual development. Although our findings are only suggesting this, it seems that for a young person in the Netherlands having a job then, either stable or unstable, represents a further piece of independence. Conversely, for a young person in Italy this same condition might not satisfy the need for independence since it doesn't overcome the issue of economical and in turn affective bound to the family of origin.

Overall, the results from this study can be read through the lens of the conservation of resources theory (Hobfoll, 1989). The lack of resources in the national context for Italian young adults can be seen as a drawback to reach adulthood in comparison with those experienced by their Dutch peers in their country. The latter are thus more prone to invest in individual domains which do not seem to involve any more emotional ties with parents (which may also reflect a different conception of being independent in the Italian culture). As confirmed by sociological studies (e.g., Buzzi et al., 2002; Scabini et al., 2006), in Italy and in others southern European countries, family ties become stronger through the generations, therefore to consider him/herself as an "adult" one doesn't take into account the emotional ties with parents but rather the acquisition of responsibilities and the establishment of a relationship with them on an equal basis. These findings have important implications for future research on the topic of the transition to adulthood as they provide evidence on the basis of which individual characteristics emerging adults experience and perceive their path to adulthood differently. Specifically, the main contribution of this study is to have tested such hypotheses in a cross-national manner where contextual and individual differences are both taken into account.

\section{Limitations}

This study has some limitations. First of all, it is important to point out that we focused on a specific fraction of the working population in our two national groups, namely university working students, therefore their scores cannot be generalized in comparison with other non-student groups. For example, as reminded by Nelson and Barry (2005) there is still relatively little that is known about individual differences in young people who do not attend college after high school, especially on issues related to criteria for adulthood, attitudes and believes about marriage and family life and identity formation. On a related note, students might be more incline to accept temporary job contracts as they are more adapt to their flexible needs (for example studying or planning to go abroad). Future studies then should also control for volition and reasons for accepting temporary employment to further distinguish among working students' individual characteristics. However, given that in Italy recent surveys pointed out that more than half of the population of students after university declare to have been also employed during the years of university (Centro di preparazione esami Universitalia, 2009) and that in the Netherlands working students have a significant impact in employment rates (Van der Meer \& Wielers, 2001), findings from this present study are relevant for a good portion of young people at least in these two countries. At last, as reminded in the analysis section, a further limitation of this study regarded the small sample size that cannot be representative of the normal population and is problematic to measure invariance across groups (Hu \& Bentler, 1999). Future research should adopt larger samples to prove with more precision that every sub-scale doesn't encompass different concepts in different national groups of individuals.

\section{Strengths and implications for future research}

Findings from this study might have implications for future research. Firstly, it adopted a set of measures that were never been before used in a cross-national setting between different European countries. In this way, it increases the knowledge on the theory upon transition to adulthood by pointing out as the two national groups differed significantly on more than one aspect. These differences meant that it would be interesting to discern young adults' perception of adulthood according to specific national characteristics also in others contexts. Moreover, future work could examine the developmental changes that occur in the criteria individuals have for adulthood. It is possible that the criteria one deems to be important for adulthood changes at some point during one's lifespan. Past research suggests that although emerging adults do not list being a parent as an important criterion for adulthood, nearly all emerging adults when have become parents list parenthood as the marker that defines them as an adult (Galinsky, 1981). In other words, personal experiences, for example becoming a parent or even being involved in a romantic relationship, may change one's perception of adulthood (van Dulmen, Goncy, Haydon \& Collins, 2008). This change in perspective may even occur several times across the lifespan. Although several crosssectional approaches have been undertaken to examine these differences at various points across the lifespan (e.g., Arnett, 2000; Bangerter, Grob, \& Krings, 2001), longitudinal research is needed to determine how emerging adults' criteria for adulthood change as emerging adults 
age and experience many of the markers they considered important for reaching adulthood. Nevertheless, despite the weaknesses, the cross-national nature of the research has allowed us to explore a theoretical model between diffent European countries, and thus may contribute to our understanding of the phenomenon of transition to adulthood.

\section{References}

Amable, M. Benach, J., \& González, S. (2001). La precariedad laboral y su repercusión sobre la salud: Conceptos y resultados preliminares de un estudio multimétodos [Job insecurity and its impact on health: Concepts and preliminary results from a multi-method study]. Archivos de Prevencion y Riesgos Laborales, 4(4), 169-184.

Arnett, J. J. (1998). Learning to stand alone: The contemporary American transition to adulthood in cultural and historical context. Human Development, $41,285-315$.

Arnett, J. J. (2000). Emerging adulthood: A theory of development from the late teens through the twenties. American Psychologist, 55, 469-480.

Arnett, J. J. (2001). Conceptions of the transition to adulthood: Perspectives from adolescence through midlife. Journal of Adult Development, 8, 133-143.

Arnett, J. J. (2003). Conceptions of the transition to adulthood among emerging adults in American ethnic groups. New Directions in Child and Adolescent Development, 100, 63-75.

Arnett, J. J., \& Galambos, N. L. (2003). Culture and conceptions of adulthood. New Directions for Child and Adolescent Development, 100, 91-98.

Aronsson, G., Gustafsson, K., \& Dallner, M. (2002). Work environment and health in different types of temporary jobs. European Journal of Work and Organizational Psychology, 11(2), 151-175.

Badger, S., Nelson, L. J., \& Barry, C. M. (2006). Perceptions of the transition to adulthood among Chinese and American emerging adults. International Journal of Behavioral Development, 30, 84-93.

Baizán, P. (2001). Transitions to adulthood in Spain. In M. Corijn, \& E. Klijzing (Eds.), Transitions to Adulthood in Europe (pp. 279-312). Dordrecht, Netherlands: Kluwer.

Bangerter, A., Grob, A., \& Krings, F. (2001). Personal goals at age 25 in three generations of the twentieth century: Young adulthood in historical context. Swiss Journal of Psychology, 60, 59-64.

Barbaranelli C., \& D’Olimpio, F. (2007). Analisi dei dati con SPSS [Data analysis using SPSS]. Milano, Italy: LED.

Barker, K., \& Christensen, K. (1998). Controversy and challenges raised by contingent work arrangements. In K.Barker, \& K.Christensen (Eds.), Contingent work: American employment relations in transition (pp. 1-18). New York, NY, USA: Cornell University Press.

Barker, E. T., \& Galambos, N. L. (2005). Adolescents' implicit theories of maturity: Ages of adulthood, freedom, and fun. Journal of Adolescent Research, 20, 557-576.

Barry, C. M., \& Nelson, L. J. (2005). The role of religion in the transition to adulthood for young emerging adults. Journal of Youth and Adolescence, 34, 245-255.

Booth, A. L., Francesconi, M., \& Frank, J. (2002). Temporary jobs: Stepping stones or dead ends. Economic Journal, 112, 189-213.

Briulotta, T. (2009). Atipici in famiglia. La vita a due nell'incertezza lavorativa [Atypical family: Couples living in working uncertainty]. In R. Palidda (Ed.) Vite flessibili. Lavori, famiglie e stili di vita di giovani coppie meridionali [Flexible lives: Jobs, families and lifestyles of young couples in the South] (pp.135-165). Milano, Italy: Franco Angeli.

Buhl, H. (2007). Well-being and the child-parent relationship at the transition from university to work life. Journal of Adolescent Research, 22, 550-571.

Buzzi, C., Cavalli, A., \& De Lillo, A. (2002). Giovani del nuovo secolo: quinto rapporto IARD sulla condizione giovanile in Italia [Young people in the new century: The fifth IARD report on the youth in Italy]. Bologna, Italy: Il Mulino.

Centro di preparazione esami Universitalia. (2009). Di giorno studenti, di notte camerieri [Students during the day, waiters in the night] (Press release). Retrieved from www.universitalia.it

Cheah, C. S. L., \& Nelson, L. J. (2004). The role of acculturation in the emerging adulthood of aboriginal college students. International Journal of Behavioral Development, 28, 495-507.

Ciairano S., Rabaglietti E., Roggero A., \& Callari, T. C. (2010). Life satisfaction, sense of coherence and job precariousness in Italian young adults. Journal of Adult Development, 17(3), 177-189.

Cohany, S., Hipple, S., Nardone, T., Polivka, A., \& Stewart, J. (1998). Counting the workers: results of a first survey. In K. Barker, \& K. Christensen (Eds.), Contingent work: American employment relations in transition (pp. 41-68). New York, NY, USA: Cornell University Press.

Corijn, M., \& Klijzing, E. (Eds.). (2001). Transitions to Adulthood in Europe. Dordrecht, Netherlands: Kluwer.

Cook, T. D., \& Furstenberg, F. F. Jr. (2002). Explaining aspects of the transition to adulthood in Italy, Sweden, Germany, and the United States: A cross-disciplinary case synthesis approach. The Annals of the American Academy of Political and Social Science 580:257-87.

Crocetti, E., Rabaglietti, E., \& Sica, L.S. (2012). Personal identity in Italy. New Directions for Child and Adolescent Development, 138, 87-102. 
Crocetti, E., Schwartz, S. J., Fermani, A. Klimstra, T., \& Meeus, W. (2012). A cross-national study of identity status in Dutch and Italian adolescents. European Psychologist, 17(3), 171-181.

De Lillo, A. (2007). I valori e l'atteggiamento verso la vita [The values and attitude towards life]. In C. Buzzi, A. Cavalli, \& A. De Lillo (Eds.), Rapporto giovani: Sesta indagine dell'Istituto Iard sulla condizione giovanile in Italia [Report youngsters: Sixth IARD Institute survey on youth in Italy] (pp. 139-160). Bologna, Italy: Il Mulino.

De Witte, H. (1999). Job insecurity and psychological well-being: Review of the literature and exploration of some unresolved issues. European Journal of Work and Organizational Psychology, 8, 155-177.

De Witte, H. (2005). Job insecurity: Review of the international literature on definitions, prevalence, antecedents and consequences. SA Journal of Industrial Psychology, 31, 1-6.

Dolado, J., García-Serrano, C. \& Jimeno, J. (2002). Drawing lessons from the boom of temporary jobs in Spain. Economic Journal, 112, 270-295.

Eurostat (2009). Youth in Europe: A statistical portrait. Retrieved from http://epp.eurostat.ec.europa.eu/ cache/ITY_OFFPUB/KS-78-09-920/EN/KS-78-09920-EN.PDF

Facio, A.. \& Micocci, E. (2003). Emerging adulthood in Argentina. New Directions in Child and Adolescent Development, 100, 21-31.

Facio, A., Resett, S., Micocci, F., \& Mistrorigo, C. (2007). Emerging adutlhood in Argentina: An age of diversity and possibilities. Child Development Perspectives, 1, $115-118$.

Fadjukoff, P., Kokko, K., \& Pulkinnen, L. (2007). Implications of timing of entering adulthood for identity achievement. Journal of Adolescent Research, 22, 504-530.

Ferrie, J. E. Westerlund, H. Virtanen, M. Vahtera, J., \& Kivimki, M. (2008). Flexible labor markets and employee health. Scandinavian Journal of Work, Environment and Health, Supplement, 6, 98-110.

Field, A. P. (2009). Discovering statistics using SPSS. London, England: SAGE.

Fierro A., D., \& Hernández, A. M. (2007). Emerging adulthood in Mexican and Spanish youth: Theories and realities. Journal of Adolescent Research, 22, 476-503.

Galinsky, E. (1981). Between generations: The six stages of parenthood. New York, NY, USA: Berkeley.

Gilmore, D. (1990). Manhood in the making: Cultural concepts of masculinity. New Haven, CT, USA: Yale University Press.

Goldscheider, F., \& Goldscheider, C. (1999). The changing transition to adulthood: Leaving and returning home. Thousand Oaks, CA, USA: Sage.

Golsch, K. (2003). Employment flexibility in Spain and its impact on transitions to adulthood. Work, Employment Society, 17, 691-718.
Harlow, L. L. (1985). Behavior of some elliptical theory estimators with nonnormal data in a covariance structural framework: A Monte Carlo study (Unpublished doctoral dissertation). University of California, Los Angeles, USA.

Hesselink, D. J. K. \& van Vuuren, T. (1999). Job flexibility and job insecurity: The Dutch case. European Journal of Work and Organizational Psychology, 8, 273-293.

Hobfoll, S. E. (1989). Conservation of resources: A new approach at conceptualizing stress. American Psychologist, 44(3), 513-524.

Hogan, D., \& Astone, N. (1986). The transition to adulthood. Annual Review of Sociology, 12, 109-130.

Hoyer, W. J., \& Rybash, J. M. (1994). Characterizing adult cognitive development. Journal of Adult Development, 1, 7-12.

Hu, L., \& Bentler, P. M. (1999). Cutoff criteria for fit indexes in covariance structure analysis: Conventional criteria versus new alternatives. Structural Equation Modeling, 6, 1-55.

International Labour Organization. (2012). Global employment trends for youth 2012 report. Geneva, Switzerland: Author.

ISTAT (Istitutio Nazionale di Statistica) (2012). Novembre 2011 (dati provvisori) e III trimestre 2011 Occupati e Disoccupati. Press released, January 5, 2012. Retrieved from www.istat.it

Kahn, L. M. (2007). The impact of employment protection mandates on demographic temporary employment patterns: international microeconomic evidence, Economic Journal, 117, 333-356.

Kahn, L. M. (2009). Temporary jobs and job search effort in Europe: IZA discussion papers, No. 4020. Retrieved from http://ftp.iza.org/dp4020.pdf

Kalleberg, A. K. (2009).Precarious work, insecure workers: employment relations in transition, American Sociological Review, 74, 1-22.

Lanz, M., \& Tagliabue, S. (2007). Do I really need someone to become adult? Romantic relationships in emerging adulthood. Journal of Adolescent Research, 22, 531-549.

Macek, P., Bejcek, J., \& Vanýckova, J. (2007). Contemporary Czech emerging adults: Generation growing up in the period of social changes. Journal of Adolescent Research, 22, 444-475.

Mayseless, O., \& Scharf, M. (2003). What does it mean to be an adult? The Israeli experience. New Directions in Child and Adolescent Development, 100, 5-20.

McKee-Ryan, F. M., Song, Z., Wanberg, C. R., \& Kinicki, A. J. (2005). Psychological and physical well-being during unemployment: A meta-analytic study. Journal of Applied Psychology, 90, 53-76.

Meeus, W. H. J. (2006). Netherlands. In International Encyclopedia of Adolescence (pp. 666-680). New York, NY, USA: Routledge.

Modell J., Furstenberg, F. F. Jr., \& Hershberg, T. (1976). Social change and transitions to adulthood in historical perspective. Journal of Marriage and the Family, 38, 7-32. 
Muthen, B., \& Kaplan, D. (1985). A comparison of some methodologies for the factor analysis of non-normal Likert variables. British Journal of Mathematical and Statistical Psychology, 38, 171-189.

Naldini, M. (2003). The family in the Mediterranean Welfare States. London, United Kingdom; Portland, OR, USA: Frank Cass.

Nelson, L. J., \& Barry, C. M. (2005). Distinguishing features of emerging adulthood: the role of selfclassification as an adult. Journal of Adolescent Research, 20, 242-262.

Nelson, J. N., Padilla-Walker, L. M., Carroll, J. S., Madsen, S. D., McNamara Barry, C., \& Badger, S. (2007). If you want me to treat you like an adult, start acting like one! Comparing the criteria that emerging adults and their parents have for adulthood. Journal of Family Psychology, 21, 665-674.

Newton, P. M. (1994). Daniel Levinson and his theory of adult development: A reminiscence and some clarifications. Journal of Adult Development, 3, 135-147.

Organisation for Economic Co-operation and Development. (2002). Employment Outlook. Paris, France: Author.

Paleari, F. G., Rosnati, R., \& Lanz, M. (2002). Il supporto nelle relazioni familiari e il benessere dei giovani adulti: Differenze di prospettiva [Support in family relations and young adults' well-being: Differences of perspectives]. Ricerche di Psicologia, 25(4), 39-56.

Paul, K. I., \& Moser, K. (2009). Unemployment impairs mental health: Meta-analyses. Journal of Vocational Behavior, 74, 264-282.

Petrogiannis, K. (2011). Conceptions of the transition to adulthood in a sample of Greek higher education students. International Journal of Psychology and Psychological Therapy, 11(1),121-137.

Piumatti, G., Pipitone, L., Di Vita, A. M., Latina, D., \& Rabaglietti, E. (2013). Transition to adulthood across Italy: A comparison between Northern and Southern Italian young adults. Journal of Adult Development, 21(1), 1-12. Retrieved from http://link.springer. com/article/10.1007/s10804-013-9174-6

Polivka, A. (1996, October). Contingent and alternative work arrangements, defined. Monthly Labour Review, 119, 3-9.

Raaijmakers, Q. (1999). Effectiveness of different missing data treatments in survey with Likert-type data: introducing the relative mean substitution approach. Educational and Psychological Measurement, 59, 725-748.

Roggero, A., Vacirca, M. F., Mauri, A., \& Ciairano, S. (2012). The transition to cohabitation: The mediating role of self-efficacy between stress management and couple satisfaction. Journal of Alternative Medicine Research, 4(3), 325-339.

Scabini, E., Lanz, M., \& Marta, E. (2006). The transition to adulthood and family relations: An intergenerational perspective. New York, NY, USA: Psychology Press.
Schömann, K., Rogowski, R., \& Kruppe, T. (1998). Labour market efficiency in the European Union employment protection and fixed-term contracts. London, United Kingdom: Routledge.

Sennett, R. (1998). The corrosion of character: The personal consequences of work in the new capitalism. New York, NY, USA: W.W. Norton.

Simó Noguera, C., Castro Martín, T., \& Soro Bonmatí, A. (2001). Changing pathway in the transition to adulthood in Spain: Labor market, marriage and fertility patterns of young people in the last decades. Bielefeld, Germany: University of Bielefeld.

Sirsch, U., Dreher, E., Mayr, E., \& Willinger, U. (2009). What does it take to be an adult in Austria? Views of adulthood in Austrian adolescents, emerging adults, and adults. Journal of Adolescent Research, 24, 275-292.

Staff, J., Sabates, R., Harris, A., \& Briddell, L. (2011). Uncertainty in early occupational aspirations: Role exploration or floundering? Social Forces, 2, 659-683.

Statistic Netherlands (2011). Netherlands drifting further behind in $R \& D$. Retrieved from www.cbs.nl

Sutin A. R., Costa, P. T. Jr (2010). Reciprocal influences of personality and job characteristics across middle adulthood. Journal of Personality, 78, 257-288.

Sverke, M., \& Hellgren, J. (2002). The nature of job insecurity. Understanding employment uncertainty on the brink of the new millenium. Applied Psychology: An International Review, 51, 23-42.

Trempala, J., \& Malmberg, L. E. (1998). The anticipated transitiontoadulthood:Effectsofcultureandindividual experience on Polish and Finnish adolescents' future orientations. Journal of Psychology, 132, 255-266.

Uchitelle, L. (2006). The disposable American: Layoffs and their consequences. New York, NY, USA: Alfred A. Knopf.

Van der Meer, P. and Wielers, R. (2001). The increased labour market participation of Dutch students. Work, Employment and Society, 15, 55-71.

van Dulmen, M. H. M., Goncy, E. A., Haydon, K. C., \& Collins, W. A. (2008). Distinctiveness of adolescent and emerging adult romantic relationship features in predicting externalizing behavior problems. Journal of Youth Adolescence, 37, 336-345.

Vives, A., Amable, M., Ferrer, M., Moncada, S., Llorens, C., Muntaner, C., Benavides, F. G., \& Benach, J. (2013). Employment precariousness and poor mental health: Evidence from Spain on a new social determinant of health. Journal of Environmental and Public Health, 2013.

Voss, E. (2013). The role of temporary agency work and labour market transitions in Europe: Institutional frameworks, empirical evidence, good practice and the impact of social dialogue. Brussels, Belgium: European Confederation of Private Employment Agencies. 
Wilthagen, T. (1998). Flexicurity: A new paradigm for labour market policy reform? Retrieved from http://ssrn.com/abstract=1133924 or http://dx.doi. org/10.2139/ssrn.1133924 